
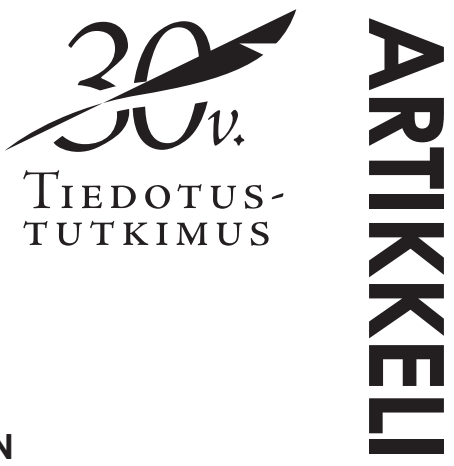

\title{
FORSSKÅL, CHYDENIUS, ARWIDSSON JA SNELLMAN SANANVAPAUS- JA JULKISUUSKYSYMYSTEN ÄÄRELLÄ
}

\begin{abstract}
Vaikka Petter Forsskålia, Anders Chydeniusta, A.I. Arwidssonia ja J.V. Snellmania ei voi pitää varsinaisesti tiedotusoppineina, beidän sananvapautta ja julkisuutta koskevat pobdiskelunsa nostavat heidät silti jalustalle erä̈nlaisina alamme suomalaisina arkkivaareina. Heidän näet voidaan sanoa artikuloineen ajattelussaan sellaisia edellytyksiä, joiden vallitessa modernin joukkoviestinnän kehitys käy mahdolliseksi. Luon artikkelissa katsauksen heidän sananvapaus- ja julkisuusnäkemyksiinsä, jos kobta painopiste on kolmen ensiksi mainitun pohdiskeluissa. Taustoitan näitä näkemyksiä eri ajankohtien poliittisia ja taloudellisia oloja koskevilla näkökohdilla ja tarkastelen näiden näkemysten ybteyksiä ajankobtien yleisempiin henkisiin virtauksiin.
\end{abstract}

Tiedotustutkimus 2008:3 $31: 3,55-72$ 
vista yleisistä kanssakäyntisäännöistä." 1700-luvun edetessä Pohjolan perukoillakin alkoi ilmetä paineita tähän suuntaan, jos kohta kehitystä rajoittivat valtakunnalle tuolloin ominaiset taloudellis-poliittiset seikat.

\section{SANANVAPAUS- JA JULKISUUSAJATTELUN TALOUDELLIS-POLIITTISTA TAUSTAA 1700-LUVUN RUOTSISSA}

Vuosien 1719-1772 välinen aika Ruotsissa oli säätyvallan aikaa, jolloin valtiollinen valta oli valtiopäiville säännöllisin väliajoin kokoontuneilla säädyillä. Valtakunnan talous rakentui tänä aikana merkantilistisille periaatteille. Elinkeinoelämää hallitsi, kuten Eero Matinolli $(1960,63)$ on kiteyttänyt, noiden periaatteiden mukainen
sääntelyjärjestelmä. Kaupankäyntiä rajoitti vuonna 1724 julkaistu tuoteplakaatti, ja ammatinharjoitusta kahlehtiva ammattipakko oli jatkuvasti voimassa. Tähän talouspolitiikkaan liittyi myös aika- kaudelle ominainen palveluspakko muuttokieltoineen ja lukuisine muine rajoituksineen.

Tässä yhteydessä on erityisen kiintoisaa, että Habermasin historiallisen erittelyn mukaan juuri talouden kehitys merkantilistiseksi kylvi porvarillisen julkisuuden siemeniä. Yhtäältä merkantilismi nykyaikaisti taloussuhteita siinä mielessä, että hallitsijan taloudenpito ja valtiontalous erkaantuivat toisistaan (Habermas 2004, 42). Tämä vei kehitystä kohti tavaranvaihdon ja yhteiskunnallisen työn pohjalle rakentuvaa kansalaisyhteiskuntaa. Toisaalta merkantilistinen sääntely rasitti porvaristoa muun muassa ehkäistessään sen vapaata toimintaa kansalaisyhteiskunnassa (emt., 49). Tilanne "sytyttikin siinä vastareaktion: publicum, julkisen vallan abstrakti vastakohtio tiedosti itsensä tuon vallan vastavoimaksi, kehkeytyvän porvarillisen julkisuuden julkisoksi” (emt., 49-50).

Näin suoraviivainen kehitys ei toki ollut, ainakaan Ruotsissa. Claes-Göran Holmbergin, Ingemar Oscarssonin ja Per Rydénin $(1983,13)$ mukaan valtakuntaan alkoi kehkeytyä porvarillisen julkisuuden ituja jo säätyvallan ensi vuosikymmeninä: virkamiehistä, lääkäreistä, kauppiaista ja muista vastaavien ammattien harjoittajista oli sukeutumassa

porvariskerrostuma, josta tuli uuden lukevan yleisön ydin. Kahviloissa, lukuseuroissa ja salongeissa virisi julkista keskustelua valtiollis-yhteiskunnallisista kysymyksistä. Keskustelu jatkui sitten painokirjoituksissa, pamfleteissa, kirjoissa ja sanoma- ja aikakauslehdissä. Aiemmin esivallan välikappaleena toimineesta lehdistöstä tuli vähitellen foorumi, jolla sivistyneet maallikot saattoivat keskustella tieteellisistä, poliittisista ja kulttuurikysymyksistä. ${ }^{1}$

Kirjoittajien mukaan tällainen kehitys"toteutui hyvin hitaasti ja konservatiivisten voimien pannessa lujasti vastaan" (emt.). Konservatiivisilla voimilla tarkoitettaneen ennen muuta aatelia. Siirtyminen säätyvaltaan oli lakkauttanut kuninkaan yksinvallan, mutta toisaalta tilalle oli astunut eräänlainen aatelin "sääty-yksinvalta”. Valtiosäädythän eivät olleet yhdenvertaiset. Julkisuuden hidasta kehitystä 
selittänee se, ettei aateli hallitsevana säätynä ollut sen tarpeessa. Kaikesta huolimatta tuonaikaiset, sinänsä harvalukuiset ja yleensä lyhytikäiset valistavat lehdet ja muut julkaisuväylät tarjosivat mahdollisuuden käydä jonkinmoista - jos kohta sensuurin rajoittamaa - julkista keskustelua muun muassa talouspoliittisista asioista. Keskustelun asetelmana ei kuitenkaan ollut porvaristo vastaan julkinen valta, kuten edellä olleen Habermas-lainauksen perusteella olisi voinut ounastella, vaan niin porvariston kuin julkisen vallankin piirissä merkantilismia sekä puollettiin että arvosteltiin (ks. Virrankoski 1986, 79-91).

On joka tapauksessa merkittävää, että valtakunnan virallista talouspolitiikkaa myös vastustettiin vaatimalla vapaamman talousjärjestelmän nimissä merkantilistisen sääntelyn väljentämistä tai jopa purkamista kokonaan. Nämä vaatimukset loivat osaltaan pohjaa vaatimuksille sananvapaudesta. Painotoimintaa oli Ruotsin valtakunnassa rajoitettu jo Kustaa Vaasan ajoista, aluksi "sääntelemättömästi ja miltei satunnaisesti” (Kastari 1981, 19), mutta 1600-luvun puolivälistä lähtien toiminnasta tuli säännellympää askel askeleelta toteutetun painotuotteiden ennakkotarkastusjärjestelmän muodossa (emt., 20-23; Manninen 1996, 110-116). Sensuuri lienee toiminut kohtalaisen tiukasti. Vaikka esimerkiksi valtakunnan virallista talouspolitiikkaa sai arvostella, kunhan arvosteluun "ei sisältynyt kovin kunnialle käyviä hyökkäyksiä itse valtiovaltaa vastaan" (Virrankoski 1986, 83), painatuslupia muodollisesti valvova kansliakollegio kielsi vuonna 1750 toimeenpantavana olevien säädösten julkisen tutkimisen ja arvostelun sen jälkeen kun "valtiontaloutta ja elinkeinoelämää käsittelevissä painokirjoituksissa" oli arvosteltu tuolloin vallassa olleen hattupuolueen hallituksen talouspolitiikkaa (Manninen 1996, 113). 1750-luvulla annettiin muitakin julkaisutoimintaa koskevia kieltoja (emt., 114; ks. myös Holmberg, Oscarsson \& Torbacke 2000, 136-138).

Sananvapausvaatimukset etenivät kahta linjaa. Yhtäältä vaadittiin vallankäytön salassapidon väljentämistä eli käytännössä avoimempaa valtiopäiväjulkisuutta. ${ }^{2}$ Toisaalta vaadittiin sensuurin rajoittamista eli suurempaa mielipiteen ilmaisu- ja kirjoitusvapautta. Nämä vaatimukset kytkeytyvät toisiinsa loogisesti siten, että ollakseen mielekästä julkinen poliittinen mielipiteenilmaisu edellyttää tietämystä siitä, mitä asioita päättävissä elimissä käsitellään ja mitä niistä siellä ajatellaan.

Sami Mannisen (1996, 95-102) mukaan vaatimusta valtiopäiväjulkisuudesta perusteltiin vetoamalla ensinnäkin siihen, että valtiopäiväedustaja on saanut valtuutuksen hänet valinneelta säädyltä ja että hän on näin velvollinen tiedottamaan valtiopäivätoimistaan valitsijoilleen. Habermasin $(2004,296)$ mukaan tällainen sidottu valtuutus on ollut tyypillinen "eri säätyedustuslaitoksille". Ruotsissa näin ei kuitenkaan ollut (Virrankoski 1986, 125). Valtiopäivillä tuo sidottuun valtuutukseen nojaava perustelu torjuttiinkin katsomalla, että edustajan valtuutus on vapaa eli että hän ei edusta vain valitsijoitaan vaan tekee koko valtakuntaa koskevia ratkaisuja (Manninen 1996, 100-101). Tämän salassapidon säilyttäneen päätöksen ei kuitenkaan katsottu estävän mielipiteen ilmaisua eikä keskustelua "asioista niin kauan kuin ne olivat vielä harkittavina" (emt.), mutta käytännössä tämä valtiopäivien kannanotto vuodelta 1747 ei liberalisoinut ilmaisuvapautta kahlehtinutta valvontaa, joka päinvastoin kiristyi 1750-luvulla (vrt. emt., 112-114).

Astetta jyrkemmän perustelun valtiopäiväjulkisuuden puolesta esitti aluksi hattupuoluetta edustanut mutta sittemmin myssyksi kääntynyt ja nuorem-

Tiedotustutkimus 2008:3 
pien myssyjen johtohahmoksi kohonnut kauppaneuvos Anders Nordencrantz 1750-luvun lopun ja 1760-luvun alun kirjoituksissaan (Danielson-Kalmari 1932, 348-350; Manninen 1996, 105-106; Virrankoski 1986, 95-103). Hänestä salassapitojärjestelmä mahdollisti virkamiesten väärinkäytökset. Tästä syystä kansalaisten mahdollisuuksia valvoa politiikkaa ja hallintoa tuli kohentaa "lisäämällä julkisuutta, laajentamalla painovapautta ja jakamalla kansalle poliittista valistusta" (emt., 101).

Ilmaisu- ja kirjoitusvapauden osalta Nordencrantz ei ajanut sensuurin poistamista mutta kylläkin sen siirtämistä säätyjen valvontaan. Sensuurille kaavailemissaan ohjeissa hän edellytti "lähes täydellistä painovapautta, lähinnä vain sävyltään loukkaavat kirjoitukset pitäisi kieltää” (emt., 187). Hänestä jopa kapinallisten ja yhteiskunnallisesti vahingollisten kirjoitusten julkaiseminen voitaisiin sallia, koska niiden harhakäsitykset voitaisiin julkisesti kumota. Mutta jos hän edellytti näin laajaa painovapautta, miksi sensuuri olisi yhä tarpeen? Pentti Virrankoski (1986) tulkitsee Nordencrantzin ajatelleen, että säädyille uskottu sensuuri olisi hänen ajamansa politiikan kannalta parempi ratkaisu kuin mikään muu. Siten hän olisi kannattanut "painovapautta vain tiettyyn rajaan asti ja omasta näkökulmastaan katsoen" (emt., 187-188).

Vielä 1760-luvulle tultaessakaan vaatimukset sananvapaudesta eivät olleet saaneet paljoa aikaan. Valtiopäivien ovi oli tosin hieman raottunut, mutta ei niinkään asiaa ajaneen argumentaation ansiosta kuin erinäisistä etukamppailuista johtuen. 1750-luvun alussa esiin tulleet pyrkimykset vahvistaa kuninkaan valtaa loivat ylinten valtioelinten välille ristiriitoja, ja tässä tilanteessa asianosaiset "katsoivat parhaaksi kääntyä valitsevien säätyjen ja viime kädessä yleisön puoleen saadakseen omille käsityksilleen kansalaisten kannatuksen" (Manninen 1996, 103). ${ }^{3}$ Tuolloin vallassa olleen hattupuoleen aloitteesta alettiin julkaista salassapitoperiaatetta horjuttanutta lehteä nimeltä Riksdags-Tidningar. Se nimittäin julkisti valtiopäiviltä sellaista aineistoa, jollaisen julkitulon salailupolitiikka oli aiemmin estänyt (Holmberg, Oscarsson \& Rydén 1983, 23-24). Merkittävä oli myös hattupuolueen oma propagandalehti En Ärlig Swensk. Lehdessä ajettiin sitä kantaa, että jos kuninkaan valtaa pyritään lisäämään säätyjen kustannuksella, kansalla on oikeus asettua vastarintaan. Painovapaus taas oli tarpeen, jotta kansa saisi kyseisen oikeuden kannalta tähdellistä tietoa (Manninen 1996, 103-105; Holmberg, Oscarsson \& Torbacke 2000, 139-140). Jälkimmäinen lehti oli lyhytikäinen, kun taas Riksdags-Tidningaria julkaistiin myöhemminkin valtiopäivien ollessa koolla (emt., 274-275).

Tällainen oli taustoineen se käytetyn lähdekirjallisuuden kertoma käytännöllinen ja henkinen poliittis-taloudellinen tilanne, jossa Forsskål ja Chydenius astuivat areenalle.

\section{PETTER FORSSKÅL JA KYSYMYS KANSALAISVAPAUDESTA}

Edellä kuvatuilla, suurempaa taloudellista ja henkistä vapautta vaatineilla ajatuskuluilla Ruotsissa oli juurensa vankasti aikakauden eurooppalaisissa ajatusvirtauksissa. Tämä pätee myös Forsskålin ajatuksiin jo mainitussa kirjasessa Tankar om borgerliga friheten (Forsskål 1759/1989). ${ }^{4}$ Hän opiskeli Uppsalassa ja Göttingenissä teologiaa, filosofiaa ja luonnontieteitä (Matinolli 1960, 
pääaineensa. Etenkin tuolloiset opinnot näyttävät muokanneen hänen ajatuksiaan kansalaisvapauskirjoituksen suuntaan. Göttingenin yliopisto sijaitsi Hannoverin ruhtinaskunnassa, joka oli personaaliunionissa Englannin kanssa ja jossa tämän ansiosta vallitsi huomattavasti vapaamielisempi henki kuin Saksan muissa ruhtinaskunnissa (emt., 26-28; vrt. myös Habermas 2004, 119). Sikäläisten valistusmiesten välityksellä Forsskål omaksui englantilaisia ja ranskalaisia valistusaatteita, eikä hän jäänyt vain niiden jäljittelijäksi vaan pystyi” suhtautumaan niihin omintakeisesti” (Matinolli 1960,76).

Forsskål tarkoitti sekä ruotsiksi että latinaksi kirjoittamansa kansalaisvapauskirjoituksen väitöskirjakseen. ${ }^{5}$ Kirjoitus jakautuu 20 pykälään ja on varsin lyhyt, tuskin edes tässä lehdessä julkaistavien artikkelien mittainen. Ensimmäisen pykälän mukaan tärkeintä ihmiselle on hengen lisäksi vapaus, josta kukaan ei luovu muuten kuin pakosta (Forsskål 1759/1989, 27). Toisessa pykälässä todetaan, että koska meillä on taipumusta pahuuteen ja vääryyksiin, vapaudesta on poistettava rajoituksin tämä sen vahingollinen puoli. Tällöin ihmiselle jää vapaus toimia "oikein, hyödyttää muita ja itseään sekä olla vahingoittamatta mitään" (emt.). Kolmannen pykälän mukaan "yhteiskunnassa, jossa kukin voi toimia näin, vallitsee oikea kansalaisvapaus" (emt.). Näissä kolmessa pykälässä Forsskål asetti kirjoituksensa aksiomaattiset lähtökohdat.

Kolmessa seuraavassa pykälässä hän hahmotteli tätä vapautta uhkaavia vaaroja. Vaarana ovat muun muassa maan mahtavat, koska he voivat käyttää valtaansa helposti väärin. Tosin myös kansalaiset voivat sortaa toisiaan, mikä sekin on vapaudelle vaaraksi. Silti mahtavat - etunenässä hallitsijat - ovat vapaudelle vaarallisimpia siksi, että he voivat helposti tehdä vääryyksiä ja salata ne kansalaisilta (emt.). Forsskålin näkemys tästä asiasta muistuttaa edellä kuvattua Nordencrantzin käsitystä. Kuudes pykälä päättyi kantaan, että vääryydet paljastuvat vääjäämättä, ”jos kuka tahansa saa julkisissa kirjoituksissa ottaa sopivalla tavalla puheeksi ne, jotka toimivat yleistä etua vastaan” (emt.). Seitsemäs pykälä kiteytti tältä pohjalta sen ydinajatuksen, että "kansalaisvapauden elämä ja voima perustuvat siis ennen muuta hallitusvallan rajoittamiseen ja rajattomaan painovapauteen" (emt., 27-28). Tosin rajattomaankaan painovapauteen eivät kuulu "siivottomat, Jumalaa häpäisevät, hallitusta ja yksityisiä loukkaavat ja paheisiin yllyttävät kirjoitukset" (emt., 28).

Kirjoituksensa jatkossa Forsskål perusteli eri argumentein kansalaisvapauden merkityksen ohella sitä tukevan painovapauden hyödyllisyyttä. Se esimerkiksi "kohottaa tieteet huippuunsa, raivaa pois kaikki vahingolliset säädökset, kahlitsee virkamiesten viettymystä vär̈rinkäytöksiin ja on vapaassa valtakunnassa hallituksen lujin turva" (emt.). Viimeisessä pykälässä hän korosti vapaan yhteiskunnan tärkeänä oikeutena sitä, että kaikki voivat vapaasti edistää yhteistä hyvää, mutta totesi tämän edellyttävän, "että kukin saa asianmukaista tietoa yhteiskunnan tilasta ja että jokaisella on oikeus lausua siitä mielipiteensä" (emt., 31). Kansalaisten, "joiden tulee antaa oikeita neuvoja", pitää tästä syystä saada perehtyä maata ja sen hyvinvointia koskeviin asioihin (emt.):

Kun koko maan olot tunnetaan, ainakin tarkkasilmäisimmät näkevät, mistä on hyötyä ja mistä haittaa, ja he kertovat sen kaikille, jos vain tarpeellinen painovapaus on voimassa. Yleistä neuvonantoa ohjaisivat tällöin aina totuus ja rakkaus isänmaahan, jonka yhteinen hyvinvointi on edellytys jokaisen yksityisen hyvinvoinnille. 
Forsskålin sananvapausteeseissä on syytä kiinnittää huomiota kahteen seikkaan. Ensinnäkään hän, toisin kuin esimerkiksi Nordencrantz, ei esitä sensuurin säilyttämistä. Tosin hän ei nimenomaisesti torju sitä, mutta vaatimus rajoittamattomasta painovapaudesta kyllä viittaa tähän suuntaan. On silti todettava, että hän jättää auki sen, kuinka kirjoitusten mahdollista siivottomuutta tai loukkaavuutta tulisi valvoa, siis valvottaisiinko sitä ennakkoon sensuroiden vai jälkikäteen painokantein. Forsskålin vaatimus rajoittamattomasta painovapaudesta tarkoitti Mannisen mukaan $(1996,115)$ edelleen sitä, että" mitään aihetta tai teemaa ei lähtökohtaisesti suljettaisi keskustelun ulkopuolelle", kuten siihen asti oli erilaisin kirjoituskielloin tehty. Toinen seikka on Forsskålin näkemys painovapaudesta kansalaisten oikeutena lausua mielipiteensä ja antaa neuvoja, siis oikeutena kansalaiskeskusteluun, mihin esimerkiksi Nordencrantz ei Mannisen (emt., 106) mukaan kirjoitus- ja painovapaudella viitannut. Forsskål ajatteli, että "julkisessa keskustelussa tiivistyvä totuus voisi kirjoitusvapauden vallitessa asettua [...] ohjaamaan valtiollisen vallan käyttöä" (emt., 107). Siten hän painotti kirjoitusvapauden pontimena ainakin retorisesti valtion etua.

Ilmeisesti Forsskålin kirjoituksen kansalaislähtöisyys ja kriittisyys mahtavia kohtaan löivät kapuloita sen rattaisiin. Uppsalan yliopisto ei myöntänyt sille painatuslupaa väitöskirjana. Myös painoasiat viime kädessä ratkaiseva kansliakollegio, jonka puoleen Forsskål oli kääntynyt, epäsi painatusluvan havaittuaan kirjoituksen sisältävän "lainvastaisia ja vaarallisia periaatteita, kuten nimenomaan Laittoman Vapauden painattaa kaiken, mistä voi omantuntonsa mukaan vastata" (sit. Matinolli 1960, 67). ${ }^{6}$ Forsskål kääntyi seuraavaksi valtakunnan sensori Nils von Oelreichin puoleen ja sai tältä luvan kirjasen painattamiseen. Pääosa 500 kappaleen painoksesta jaettiin Uppsalan ylioppilaille (emt., 69). Saatuaan asiasta tiedon kansliakollegio moitti ankarasti von Oelreichia ja Forsskålia ja määräsi " 1000 hopeatalarin sakon jokaiselle, joka osti, myi tai piti hallussaan puheena olevaa kirjasta" (emt., 70). Jaettuja kirjasia saatiin jonkin verran takavarikoiduksi mutta ei ilmeisesti läheskään kaikkia.

Jupakan aikana Forsskål oli hyväksytty jäseneksi luonnontieteelliseen retkikuntaan, jonka oli määrä selvittää Arabian niemimaan kasvillisuutta ja eläimistöä. Retkikunta lähti matkalle vuoden 1761 alussa, ja tällä matkalla Forsskål menehtyi heinäkuussa 1763, vain 31 vuoden ikäisenä.

\section{ANDERS CHYDENIUS JA VUODEN 1766 PAINOVAPAUSASETUS}

Missä Forsskål astui sananvapausareenalle akateemista meriittiä tavoittelevan yksityishenkilön roolissa, siinä Chydenius astui sille valtiopäivämiehenä eli julkista valtaa edustavassa roolissa. Tämä Sotkamossa vuonna 1729 syntynyt pappismies valittiin Alavetelin kappalaisena pappissäädyn edustajaksi vuosien 1765-1766 valtiopäiville, joilla hän vaikutti merkittävästi vuoden 1766 hyvin vapaamielisen painovapausasetuksen laadintaan ja läpivientiin.

Chydeniuksen valtiopäiville valintaa kuvatessaan Virrankoski (1986, 104-121) kertoo tämän alkaneen kiinnostua taloudellisista kysymyksistä 1760-luvun alun tietämissä ja laatineen aiheesta useammankin kirjoituksen. Erityisesti Chydenius arvosteli Pohjanmaan tuolloista kauppapakkoa: pohjalaiset eivät saaneet käydä ulkomaankauppaa vaan heidän oli myytävä tuotteensa 
ne eteenpäin ja käärivät voitot taskuihinsa. Pohjalaiset olivat jo pitkään pyrkineet saamaan tapulioikeuden joillekin omista kaupungeistaan, ja Virrankosken (emt., 123) mukaan Chydenius valittiinkin edellä mainituille valtiopäiville juuri "tapulioikeuden erikoistuntijana sitä ajamaan".

Chydenius tunnetaan liberaalina talouspoliitikkona. Kirjoituksissaan hän hyökkäsi monelta suunnalta merkantilistista sääntelyjärjestelmää vastaan. Erityisesti hänen hampaisiinsa joutui tuoteplakaatti. Virrankosken mukaan (emt., 34-35; 136-144) se kielsi ulkomaalaisia tuomasta valtakuntaan muita kuin oman maansa tuotteita. Tarkoitus oli edistää näin valtakunnan oman kauppalaivaston kehitystä, mutta niin Chydeniuksen kuin muidenkin arvostelijoiden mukaan järjestelmä keskitti ulkomaankaupan Tukholman ja muiden suurten tapulikaupunkien merenkulkua harjoittaville suurkauppiaille. Tämä monopolisoituminen nosti tuontitavaroiden hintoja. Toisaalta koska ulkomaalaisia purjehti valtakuntaan vain vähän, maan omista tuotteista ei syntynyt riittävästi kilpailevaa kysyntää, joten ne jouduttiin myymään useinkin alihintaan. Tällaisista pulmista johtuen Chydenius piti vapaata kilpailua niin ulkomaankaupassa kuin muussakin elinkeinotoiminnassa paljon parempana talouspolitiikkana kuin kahlitsevien säännösten ja niiden synnyttämien etuoikeuksien ja monopolien ylläpitoa (emt., 131-150).

Kuten loogista onkin, vapaan talouspolitiikan korostus sai Chydeniuksen ajattelussa kumppanikseen pyrkimyksen vapaaseen julkisuuspolitiikkaan. Ajatukset taloudellisesta vapaudesta ja painovapaudesta olivat toki kulkeneet käsi kädessä myös Forsskålin ja Nordencrantzin kirjoituksissa. Itse asiassa Chydenius sai niin talous- kuin julkisuuspoliittisiinkin näkemyksiinsä rutkasti evästä juuri Nordencrantzin kirjoituksista (Kastari 1981, 45-50; Virrankoski 1986, passim.). Nordencrantzista Chydenius totesi elämäkerrassaan, että tämän kirjoitukset saivat hänet pitämään painovapautta "vapaan valtakunnan silmäteränä" (sit. emt., 190). Toisaalta hän tunsi Pirkko-Liisa Kastarin $(1981,50)$ mukaan hyvin myös Forsskålin ajatukset aikakauden yleisen valistusajattelun ohella. Tästäkö vai mistä johtunee, että hänen näkemyksensä painovapaudesta kehkeytyivät Nordencrantzin ajatuksia radikaalimmiksi.

Sensuurin 1750-luvulla kiristyneestä otteesta huolimatta, tai ehkä juuri siksi, kysymys painovapaudesta oli samaan aikaan noussut yhä enemmän esille. Virrankosken $(1986,186)$ mukaan vallanpitäjien kanta asiaan alkoi tuolloin ”jäädä jälkeen yleisestä mielipiteestä". Kysymys nousikin esiin jo vuosien 1760-1762 valtiopäivillä. Asiaa pohtimaan asetettu erityiselin päätyi kuitenkin sensuurin säilyttämiseen. Mietinnössään se leimasi sensuurista luopumisen "vaaralliseksi menettelyksi" (emt., 188). Toisaalta se katsoi, että virallisten asiakirjojen julkaiseminen voisi olla jopa "huomattavan laajaa" (emt.). Noiden valtiopäivien aikana sensuurin aiempi kireys alkoi löystyä. Esimerkiksi Nordencrantzin siihen asti levityskiellossa olleita keskeisiä teoksia sai nyt vapaasti levittää (emt., 187). En fri Swänsk -nimisessä lehdessä tuntematon kirjoittaja määritteli painovapauden jo näin (sit. emt.): "Täydellinen, rajoittamaton vapaus joka miehen esittää ajatuksiaan mistä tahansa ja millä tavoin tahansa, kunhan se ei ole laissa kiellettyä, tarvitsematta siihen erityistä lupaa tai privilegiota."

Chydenius ei osallistunut vielä näille valtiopäiville vaan vasta seuraaville. Niiden alkupuolella tehtiin kolme aloitetta painovapauskysymyksestä. Niistä yksi oli Chydeniuksen käsialaa, vaikka se esitettiin pappissäädyn arvovaltaisemman edustajan, lehtori Anders Kraftmanin nimissä (Kastari 1981, 51-53; Virran-

Tiedotustutkimus 2008:3 
koski 1986, 190-194). Tätä varsinaista aloitemuistioita edelsi luonnos. Koska varsinainen aloitemuistio on - ilmeisesti säätykumppanien hillitsevien neuvojen tuloksena - jossain määrin siistitty versio luonnoksesta, kiinnitän seuraavassa huomioni juuri luonnokseen, joka edustanee Chydeniuksen näkemyksiä autenttisemmin kuin lopullinen versio.?

Chydenius $(1765 / 1929,165)$ totesi aksiomaattisena lähtökohtanaan, että "kohtuullinen kirjoitus- ja painovapaus on lujimpia peruspilareista, joiden varassa vapaa hallitustapa voi säilyä", koska vain se takaa tiedon riittävän kulun niin säädyille, lainkäyttäjille kuin alamaisillekin. Tästä lähtökohdasta juontui kaksi pääkysymystä: "kenen vastuulla painamisen tulee tapahtua ja minkä lakien mukaan" (emt.). Edellisen kysymyksen osalta Chydenius puntaroi kolmea vaihtoehtoa: niistä ensimmäisessä vastuu sälytettäisiin sensorille, toisessa kirjoittajalle ja kolmannessa kirjanpainajalle. Ensimmäinen vaihtoehto säilyttäisi ennakkotarkastuksen kun taas jälkimmäisissä siitä luovuttaisiin. Sellaisista kirjoituksista, joiden katsottaisiin loukkaavan muistiossa ehdotetun painovapausasetuksen säädöksiä, olisi tällöin nostettava painokanne ja asia ratkaistava oikeudenkäynnissä.

Sensuurivaihtoehdon Chydenius tyrmäsi useammallakin perusteella ja astui näin tehdessään pitemmälle kuin Nordencrantz tai jopa Forsskål. Edellinenhän halusi säilyttää sensuurin, jos kohta säätyjen käsiin siirrettynä, ja jälkimmäinen jätti kysymyksen sensuurista tarkkaan ottaen auki. Sensuuria vastustaessaan Chydenius korosti eritoten sitä, että se johtaa helposti sensorin mielivaltaan, koska tämä voi makunsa mukaan suosia yksiä ja sortaa toisia kirjoittajia. Tähän hän liitti lopullisesta versiosta poistetun peräkaneetin (emt., 166): "Kansakunnan vapaus ei ole sitä, että kaikkivaltiaat säädyt voivat toimia mielivaltaisesti, vaan se edellyttää, että kansakunnan valistuneisuus sitoo niiden kädet ja estää niitä menettelemästä itsevaltaisesti."

Tämä kannanotto on kiintoisa, sillä se implikoi kansanvaltaa - sitä, että kansa voi vaikuttaa säätyjen toimintaan tai vähintäänkin että säädyt ovat vastuussa kansalle. Kuten Virrankoski $(1986,193)$ toteaa, kanta oli tuolloisissa oloissa vallankumouksellinen, koska voimassa olleen valtiosäännön mukaan valta kuului valtakunnan säädyille (riksens ständer), ei kansalle. ${ }^{8}$ Ei siten ihme, että virke karsiutui lopullisesta versiosta. Saman kohtalon koki toinenkin virke, jossa Chydenius $(1765 / 1929,167)$ katsoi, että ratkaisuvallan jäädessä sensorille tämä saa tilaisuuden polkea "kansalaisten oikeudet ylimysten jalkoihin". Toisaalta hän esitti vastaavansisältöisiä näkökohtia valiokuntalausunnoissaankin, esimerkiksi todetessaan, että ihmisten etuoikeus eläimiin verrattuna"sisältyy keskinäiseen ajatustenvaihtoon ja kansalaisten oikeuteen valistaa kansakuntaa" (sit. Castrén 1951, 226).

Kahdesta jäljelle jääneestä vaihtoehdoista Chydenius kallistui kirjanpainajalle sälytettävän vastuun kannalle. Kiinnostavin perustelu sille on se, että jos jokin kirjoitus todetaan painovapausasetusta loukkaavaksi, kirjanpainajalla on paremmin varaa maksaa koituvat sakot kuin yksittäisellä kirjoittajalla, jolta liikenee "usein tuskin äyriäkään" (Chydenius 1765/1929, 168). Lopullisessa asetuksessa ei kuitenkaan seurattu Chydeniusta tältä osin. ${ }^{9}$ Pääasialliseen vastuuseen asetettiin kirjoittaja, ja kirjanpainaja joutui vastuuseen vain, jos hän ei kyennyt osoittamaan kirjoittajaa. ${ }^{10}$ 
sen julkisuuden ja julkisen keskustelun muotoutumisen kannalta. Sama tulee esiin epäsuorasti jaksossa, jossa hän pyrki kumoamaan jo etukäteen väitteet, että painovapaus laukaisisi esiin vääränlaisen ajattelun tulvan (emt., 170):

\begin{abstract}
On aivan turha odottaa ihmisiltä niin täydellistä ilmaisua, että siihen ei voi sanoa vastaan eikä sitä mitenkään muuttaa. Jos ilmaisu on järjetön, piankin ilmaantuu viljalti sen kumoajia. Jos se taas perustuu totuuteen, se on kumoamaton, eikä mitään linnoitusta voida ylistää enemmän kuin sitä, joka on kestänyt pahimmankin piirityksen. Jos asia on tulkinnanvarainen, totuutta on etsittävä ajatustenvaihdossa, ja jos tämä kielletään, kielto ei voi johtua muusta kuin pelosta, että totuus tulee julki. [...] Valhe häpäisee esittäjänsä mutta hyödyttää valtakuntaa siten, että totuus perustellaan ja pääsee näin juurtumaan kunnolla.
\end{abstract}

Ilmiselvästi Chydeniuksen kantana oli, että julkinen keskustelu on ainakin periaatteessa ajatusten koetinkivi. Näkemys ei ollut sinänsä erityisen harvinainen tuonaikaisissa valistuneissa piireissä. Myös Forsskål $(1759 / 1989,28)$ ajatteli samoin todetessaan, että "vapauden vallitessa totuuden voima työntää vähitellen harhaluulot tieltään ja saa ne vähenemään". Niin Forsskålin kuin Chydeniuksenkin mielessä julkisuus näyttää väikkyneen valtaapitäviä ja kansalaisia välittävänä toimintakenttänä, jolle yksityishenkilöt kokoontuvat julkisoksi punnitsemaan poliittisen vallan toimia (vrt. Habermas 2004, 320). Ja tavallaan heidän kaavailujensa sisään oli rakentunut jo tila viestimille, jotka toimivat välikätenä niin julkisen vallan ja kansalaisten välillä (valtiopäiväjulkisuus ja julkisen vallan avoimuus) kuin kansalaisryhmienkin välillä (julkinen keskustelu), vaikka kumpikaan heistä ei vielä puhunut nimenomaisesti lehdistöstä.

\title{
AIKA VUODESTA 1766 SUOMEN SIIRTYMISEEN VENÄJÄN YHTEYTEEN
}

Toiveet painovapausasetuksen vaikutuksesta julkisuuteen eivät olleet aivan turhia. Asetuksen jälkeen maa suorastaan "tulvehti pamfletteja, kirjasia sekä sanoma- ja aikakauslehtiä" (Holmberg, Oscarsson \& Rydén 1983, 26). Tosin lehdet olivat yleensä lyhytikäisiä ja niiden levikki vaatimaton - "100-1000 kappaletta" (emt., 28) - mutta yhtä kappaletta luki yleensä usea henkilö. Lukijat edustivat etupäässä valistunutta keskiluokkaa. Siihen kuuluvien taloudellinen asema oli parantunut, mutta he tunsivat "aatelin vallan ja etuoikeuksien olevan jatkuvan nousun telkeinä" (Virrankoski 1986, 277). Poliittinen elämä olikin paljolti aatelin ja aatelittomien säätyjen kamppailua, jossa "painovapautta käytettiin estoitta tuimien, joskus hyvinkin räikeiden pamflettien tuottamiseen" (emt., 275).

Juuri "voimaperäinen poliittinen keskustelu ja agitaatio" selittää pitkälti mainittua julkaisutulvaa (Holmberg, Oscarsson $\&$ Torbacke 2000, 150). Polemiikkia ei ole pidetty kovin korkeatasoisena - jo aikalaiset valittivat, ettei "painovapaus tuonut muassaan mitään ihannetilaa" (emt., 144) - mutta on huomattava, ettei tuolloin "ollut vielä avoimen yhteiskuntakeskustelun perinnettä eikä mitään yhteistä kieltä julkista keskustelua varten” (emt., 150). Minkä tasoista polemiikki sitten olikin, siitä päästiin pian eroon, kun Kustaa III vallan kaapat-

Tiedotustutkimus 2008:3 
tuaan antoi vuonna 1774 uuden, entisestä selvästi tiukennetun painoasetuksen. Seurauksena "yhteiskuntadebatti vaimeni minimiinsä" ja "poliittisten kirjoitusten lukumäärä romahti vain jokuseen yksittäiseen nimikkeeseen vuotta kohti" (emt., 153).

Sittemmin painovapautta supistettiin tasaisesti, kunnes kuninkaan saatua attentaatissa surmansa seurasi lyhyt suojasää vuonna 1792 annetun niin kutsutun Reuterholmin painovapausasetuksen muodossa (Tommila 1980, 7). Suojasää ei kestänyt vuottakaan, kun painotoimintaa alettiin rajoittaa uudelleen erinäisin asetukseen lisätyin tiukennuksin. Kun Suomi siirtyi Venäjän yhteyteen, tämä asetus jäi voimaan "kaikkine lisineen", jos kohta siitä, "miten valvonnan tuli tapahtua", ei Päiviö Tommilan (emt., 9) mukaan ollut lähempiä määräyksiä. Pirkko Leino-Kaukiainen $(1996,128)$ puolestaan toteaa, että tuolloiset sananvapaussäännökset" olivat hajanaisia, eikä niiden sisällöstä ollut kuvaa edes sivistyneistöllä. Kuitenkin 1700-luvun perintönä katsottiin, että oikeus esittää julkisesti mielipiteitä oli valistusta ja totuutta edistävä asia."11 Tämä on yksi A.I. Arwidssonin panosta taustoittava seikka.

Niin julkisuuden sääntelytoimiin kuin Arwidssoninkin toimintaan vaikuttivat aikakauden poliittiset ja henkiset virtaukset. 1810-luvun Napoleonin sotien aikainen ja jälkeinen Eurooppa oli monella tapaa levoton. Vastakkain olivat konservatiiviset ja liberaalis-vallankumoukselliset opit. Wienin kongressissa vuonna 1815 hahmoteltiin konservatiivisen ja "vallankumousvastaisen Euroopan peruslinjat" (Klinge 2004, 122). Vallankumouksellisempi ajattelu löysi puolestaan kaikupohjaa varsinkin akateemisen nuorison piiristä, ja kymmenluvun lopulla tämä ajattelu muuttui toiminnaksi Etelä-Euroopan vallankumousliikkeissä. Julkisuusteoreettisesti vastakkaisuus ilmeni ylhäältä alas suuntautuvan autoritaarisen ja alhaalta ylös kumpuavan kansalaislähtöisen julkisuusperiaatteen vastakohtaisuutena.

Vastakohtaisuus tuli näkyviin myös 1810-luvun Suomessa, tosin ei erityisen jyrkkänä."Vallitsevan ideologian mukaan julkisuus oli valtion monopoli." (Zilliacus \& Knif 1985, 74) Tätä ideologiaa kuvaa hyvin Suomen tuolloisen hallinnon huippuihin kuuluneen C.E. Mannerheimin ajatus tehdä viralliseksi lehdeksi nostetusta Åbo Allmänna Tidningistä mielipiteen muokkaaja, jonka olisi määrä"ohjata kansakunnan harrastuksia oikeaan, tämä kansa kun ei tiedä, mitä se tahtoo eikä mitä sen todellinen etu vaatii” (sit. Tommila 1988, 82). Vallitseva katsomus oli, että hallitsevat piirit tietävät parhaiten, mikä on maalle eduksi, ja että asioiden julkinen käsittely ja varsinkin viranomaistoiminnan julkinen arvostelu on pelkästään pahasta.

Vallitsevan autoritaarisen julkisuuden varjossa iti kuitenkin jonkinasteista toisinajattelua. Etenkin Turun yliopiston nuoremman opettajakunnan Auraseuran piirissä ilmeni" saksalaisruotsalaisen mallin mukaan" radikaalimpaa ajattelua ruokkinutta "kansallisen identiteetin ja kansalaishengen etsimistä" (emt., 84). Siihen kytkeytyi myös ajatus kansalaislähtöisemmästä julkisuudesta. Esimerkiksi dosentti J.J. Tengström suositteli vuonna 1817 Aura-seuran kalenterissa yleisten asioiden julkista käsittelyä, jolloin "kukin, vaikka sivistymätönkin, voisi tuoda esille omia kokemuksiaan" (Castrén 1951, 237). Kansalaisillakin pitäisi siis olla julkinen äänensä. 


\section{A. I. ARWIDSSON JA VALTION, LAIN JA JULKISUUDEN KOLMIYHTEYS}

Padasjoella vuonna 1791 syntynyt ja Turun yliopistossa vuonna 1814 kandidaatin tutkinnon suorittanut Arwidsson sai samaisen yliopiston historian dosentuurin vuonna 1817 (Junnila 1979, 9-18). Hän osallistui alusta pitäen Aura-seuran toimintaan ja julkaisi sen kalentereissa runojaan (Ammondt 1992, 52-56). Kun kalenteri ei enää riittänyt seuran julkaisuareenaksi, yliopiston apulaiset J.G. Linsén ja J.Fr. Bergbom perustivat Mnemosyne-lehden, joka alkoi ilmestyä vuoden 1819 alusta. Arwidsson kuului alkuvaiheessa sen avustajakuntaan. Jo tässä yhteydessä on syytä mainita, että niin hänen runoutensa kuin muun kirjallisen tuotantonsa johtotähtenä oli tuonaikainen romantiikka. Siten Forsskålin ja Chydeniuksen lähestyessä sananvapaus- ja julkisuuskysymyksiä valistuksen pohjalta Arwidsson lähestyi niitä romantiikan siivittämänä. Tosin hänen ajatteluunsa sisältyi valistuksenkin perintöä, ${ }^{12}$ joten se oli eräänlainen seos historiallis-romanttisista ja vapaamielis-valistuksellisista aineksista (Castrén 1951, 230, 419).

Valtiollis-yhteiskunnallisen kirjoittelunsa motiivia Arwidsson (1823/1909, lxxx) on kuvannut näin:"Suomalaisten maanmiesteni suuri joukko nukkui raskaasti ja oli herätettävä, varsinkin tajuamaan elämää valtiossa sekä julkisuuden arvoa ja yleistä osanottoa porvarillisen yhteiskunnan kaikkiin olosuhteisiin." Varsinaisen yllykkeen poliittiseen kynäilyyn hän sai Åbo Allmänna Tidningissä vuonna 1819 julkaistusta, vallitseville oloille hyvin myötäsukaisesta kirjoituksesta, jossa muun muassa katsottiin, että Suomessa vallitsi täydellinen kirjoitusja painovapaus (Castrén 1951, 56-58; Junnila 1979, 26-27). Näistä lähtökohdista Arwidsson tähtäsi sellaiseen herätystyöhön, johon Mnemosyne osoittautui lopulta liian araksi ja säyseäksi. Niinpä hän haki lupaa oman lehden perustamiseen ja saikin sen. Åbo Morgonblad aloitti ilmestymisensä vuoden 1821 alussa.

Arwidssonin keskeisin kirjoitus sananvapaus- ja julkisuuskysymyksestä ilmestyi lehden numeroissa 24 ja 25 kesäkuun 16. ja 23. päivinä 1821 otsikolla "Tryckfrihet och offentlighet". Toisin kuin Forsskål ja Chydenius, jotka löivät lähtökohtansa lukkoon aksiomaattisesti, Arwidsson (1821/1909, 149-154) lähti liikkeelle valtioteoreettisesti. Hänen edustamansa "historiallisen koulukunnan käsityksen mukaan" valtio "oli jatkuvasti kehittyvä, 'elävä' organismi" (Rommi 1992, 21; ks. tarkemmin Castrén 1951, 173-197). Silti sellaisenakin valtio tarvitsee järjestystä, ja sen sille takaa laki. Toisaalta pitäessään yllä järjestystä laki vastustaa muutosta, joten kehittyvä valtio ja jähmeä laki ajautuvat väistämättä ristiriitaan. "Laki puolustaa jyrkästi kaikkea pysyväistä; valtio vaatii elämää ja kehitystä", Arwidsson $(1821 / 1909,151)$ totesi. Ristiriidassa lain on annettava periksi ja taivuttava "korkeamman täydentymisen vaatimuksiin" (emt., 152). ${ }^{13}$

Valtion kehittyvä elämä ilmenee sen jäsenissä, joten "näiden on siis muutettava voimassa olevat lait" (emt.). Tämä on kuitenkin mahdotonta, "ellei ole olemassa julkisuutta ja ellei jokaisella ole oikeutta [... esiintuoda havaintojaan ja kokemuksiaan. [...] Valtion ja sen edun julkinen arvosteleminen on siis ehdottoman välttämätöntä sen terveelle kehitykselle." (Emt., 153.) Tämä taas on mahdotonta, ellei ole kirjoitus- ja painovapautta: "kansan ääni sen omista toivomuksista ja yhteiskunnan parhaasta ei käy mahdolliseksi muutoin kuin kirjallisuuden ja sen levittämisvapauden kautta: se on, kirjoitus- ja painovapauden avulla" (emt.). Valtion ja lain välille kehittämänsä ristiriitasuhteen avulla

Tiedotustutkimus 2008:3 
Arwidsson loi tällä tavoin teoreettisen perustelun sananvapauden ja julkisuuden välttämättömyydelle.

Toisaalta eleganttikaan teoreettinen perustelu ei välttämättä vakuuta muita kuin teoreettisesti samalla tavoin ajattelevia. Siten Arwidssonin oli perusteltava painovapautta ja avointa julkisuutta muillakin tavoin ja eritoten torjuttava epäilyt niiden toimimattomuudesta tai vahingollisuudesta. Yksi tapa perustella painovapautta on arvostella sen rajoituksia, ja tähän sensuurikritiikkiin Arwidsson uhrasikin useamman sivun (emt., 156-162). Kun rajoitukset kohdistuivat nimenomaan kriittiseen aineistoon ja kun toisaalta kansalaisten velvollisuutena on edistää valtion toimintaa muun muassa epäkohtia ja väärinkäytöksiä paljastamalla, heräsi kuin luonnostaan kysymys, kuinka tämä edistäminen voi toteutua "semmoisen yksipuolisuuden vallitessa, jolloin vain miellyttävä mutta ei epämiellyttävä saa tulla julkisuuteen" (emt., 160). Chydeniuksen tavoin Arwidsson moitti sensuuria myös siitä, että se mahdollistaa mielivallan.

Sensuurikritiikkinsä yhteydessä Arwidsson kiinnitti erityistä huomiota lehdistöön, koska hänen mukaansa se oli muita painotuotteita raskaampien rajoitusten alainen (emt., 159-162). Hänestä sanomalehti on paras väylä tuoda julki yhteiskunnan puutteita ja epäkohtia. Juuri siksi, että sanomalehdet on katsottu tehokkaimmiksi" yleisten mielipiteiden julkaisukeinoksi", viranomaiset ovat iskeneet silmänsä erityisesti niihin (emt., 159). Mutta jos "jokapäiväiset sanomalehdet, sensuurin tai muun pakon painostamina, eivät uskalla puhua suutaan puhtaaksi aikalaisilleen, täytyy niiden muuttua vallassa olevan muodon ilkeäksi kaiuksi, joka imarrellen ylistelee kaikkia olevaisia laitoksia, tai vajota tyhjäksi köyhäsisällyksiseksi mitättömyydeksi", kun taas milloin sanomalehtiä voidaan painovapauden vallitessa "toimittaa aatteensa mukaisesti, tulee niiden olla kansan yhteishengen ilmauksena", toisin sanoen "valtiosieluna, johon voimakkaasti yhtyvät kaikki olot ja muodot, sanalla sanoen: niiden tulee olla kansan ääni kansalle" (emt., 160-161).

Arwidssonin mukaan sananvapautta oli vastustettu väittämällä, että kansa ei ole siihen kypsä, että vapautta käytetään helposti väärin ja että se johtaa lain ja vallitsevien muotojen horjuttamiseen ja mahdollistaa henkilökohtaisen loukkaamisen. Nämä kannat hän pyrki osoittamaan vastaperusteluin pätemättömiksi (emt., 164-171). Ensimmäistä kantaa vastaan hän väitti, että sananvapaus on itse asiassa edellytys kansan kypsymiseksi siihen. Väärinkäytöksiä taas hillitsee hänen mukaansa pelko tai varmuus siitä, että väärinkäytöksiä havaittaessa ne nousevat toisten julkisen arvostelun ja vastustuksen kohteeksi. Sananvapaus olisi näin itse itseään korjaavaa. Lakien horjuttaminen on puolestaan vain hyvästä, jos niistä on tullut kehityksen kahleita. Vapaa julkinen keskustelu ratkaisee sen, onko näin vai ei. Sama oikeus, joka on tarjolla lakia vastaan hyökkäävälle, on tarjolla muillekin, "ja hyvällä asialla on aina oleva taistelevat ritarinsa. Semmoisen riidan kautta väärentämätön totuus on nopeimmin selviävä." (Emt., 169) Samoin itsensä loukatuksi tuntevalla "on sama ase" kuin sillä, jota hän loukkaajana pitää: hän voi julkisesti oikaista ja ojentaa tuota henkilöä, jolloin "hyvien asiain perillä oleva yleisö on riitapuolten tuomarina" (emt., 170).

Julkisuuteen Arwidsson puuttui sananvapautta suppeammin. Hän määritteli sen kansaa koskevien asioiden käsittelyksi "kansan edessä" (emt., 171). 
käyttämisestä" (emt.). Kun jokainen hallitsevien toimenpide tulee näin julkisesti nähtäville,"se myöskin lankee yleisön tuomion alaiseksi" (emt., 172). Näissä näkökohdissa julkisuus korostuu hallitsevien piirien tilintekovelvollisuuden kannalta, jos kohta puhe yleisön tuomiosta viittaa jo kansalaisten toimintaan habermaslaisessa mielessä julkisona. Tämä näkökulma vahvistui Arwidssonin siirtyessä pohtimaan"kansan keskuudessa syntyvän julkisen äänen" luonnetta ja laatua (emt.). Hänestä tällä äänellä on ymmärrettävä avointa oikeutta

jokaiselle ehdoitta julkisesti arvostella niitä toimia, jotka koskevat valtiota kokonaisuudessaan ja koko laajuudessaan. Julkisuus [...] ei rajoitu määrättyihin henkilöihin ja muotoihin, kaiken täytyy tulla vastaamaan yhteiskunnan yleisen lain edessä. Se ei tunnusta ketään etuoikeutettua henkilöä, paitsi hallitsijan: kaikki, mikä on toimintaa valtiossa, tuottaa vastuuta kansalaisten edessä. Ja sellaiset teot, jotka eivät ole laillisen ohjeen alaisia, ne yleinen mielipide tuomitsee. [...] Tuloksena on ja pysyy, että mikä koskee yleisöä, sen tulee olla julkista, se, jonka vaikutukset tehoovat hallitusmuodon kaikkiin aineksiin, on saatettava julkison ${ }^{14}$ tuomion alaiseksi. (Emt., 172-173)

Nämä Arwidssonin näkemykset yhtäältä kiteyttävät ja toisaalta yksityiskohtaistavat jo Forsskålin ja Chydeniuksen ajattelussa alustavasti esillä olleita näkökohtia. Näillähän varsinkin julkisuus jäi aika hahmottomaksi. Arwidssonin julkisuusnäkemys muistuttaa Habermasin porvarillisen julkisuuden sitä puolta, jossa on kyse kansalaisten kokoontumisesta julkisona arvioimaan yleisiä asioita ja valtaapitävien niitä koskevia toimenpiteitä ja vaikuttamaan syntyvän julkisen mielipiteen paineen välityksellä näihin kysymyksiin. Tällainen julkisuusvisio oli tietysti jyrkässä ristiriidassa vallitsevan autoritaarisen julkisuuden kanssa, joten ei ole ihme, että Arwidssonin nämä ja muut vastaavat suurempaa vapautta edellyttäneet ajatukset herättivät hallitsevissa piireissä melkoista närää ja kiukkua. Tuloksena oli, että loppuvuonna 1821 Åbo Morgonblad lakkautettiin.

Lakkautuksen taustana oli epäilemättä levottomuuksien yltyminen tuolloisessa Euroopassa, mikä huolestutti taantumussuuntaan kallistunutta Venäjän johtoa ja sai tätä kautta Suomen viranomaiset varpailleen (Junnila 1979, 33-34, 42-45; Castrén 1951, 355-357). Tuossa tilanteessa autoritaarisen julkisuuden ja virkavaltaisuuden arvostelu vaikutti helposti vallankumousaatteiden lietsomiselta siinä missä demokratiaan ja kansan osallistumisoikeuksiin viittaava puhekin. Lakkautuksessa avainroolia näytellyt senaatin kansliatoimituskunnan päällikkö C.J. Walleen arvosteli Åbo Morgonbladin tapaista lehdistöä lukijoiden mielipiteen harhauttamisesta, nuorison yllyttämisestä levottomuuksiin ja sotkeutumisesta kirjoittajien käsityskyvyn yläpuolella oleviin asioihin (emt., 357-358). Nämä argumentit vastaavat niitä, joilla esimerkiksi Saksassa torjuttiin samaan aikaan painovapautta (ks. Pietilä 1997, 70-72). Arwidssonin argumentit painovapauden puolesta vastaavat puolestaan Saksan ja Ruotsin oppositiopiireissä esitettyjä perusteluja (Castrén 1951, 220-232).

Lakkauttaminen ei ollut ihan yksinkertainen juttu, koska Suomen muuttuneessa tilanteessa siihen ei ollut sopivia säädöksiä. Lakkautusta ajavat eivät halunneet turvautua oikeudenkäyntiin, Liisa Castrénin (emt., 360) mukaan siksi, "etteivät tähän keinoon hallitukset juuri muuallakaan turvautuneet". Asia

Tiedotustutkimus 2008:3 
hoidettiin lopulta keisarin antamalla käskykirjeellä, joten toimenpidettä voidaan hyvällä syyllä pitää mielivaltaisena oikeudenloukkauksena (emt., 371). Tämän episodin jälkeen Arwidsson julkaisi Mnemosynessä artikkelin "Betraktelser", joka tuotti hänelle alkukesästä 1822 potkut yliopistosta. Vuonna 1823 hän siirtyi pysyvästi Ruotsiin.

\section{A.I. ARWIDSSON JA J.V. SNELLMAN}

Arwidssonin herätystyö ei kaiken kaikkiaan onnistunut järin hyvin. Esimerkiksi Matti Klingen $(2004,169)$ mukaan "mikään ei viittaa siihen, että liberaaliset tai vallankumoukselliset tai edes oppositioaatteet olisivat saaneet vastakaikua Suomessa Arwidssonin välinäytöksen jälkeen”. Kestikin parisenkymmentä vuotta ennen kuin J.V. Snellman käynnisteli herätystyötä uudelleen Saima-lehdessään 1840-luvulla. Hänen sananvapautta, julkisuutta ja lehdistöä koskeva ajattelunsa on kuitenkin niin monisäikeistä, ettei sen lähempi tarkastelu mahdu tämän artikkelin puitteisiin. Sen sijaan tarkastelen joitakin yhtymäkohtia hänen ja Arwidssonin välillä valaistakseni tältä pohjalta heidän julkisuuskäsitystensä erityisyyttä.

Åbo Morgonbladin Arwidsson oli joiltain osin liberaali mutta ei siltä osin, että olisi asettanut yksilön yhteisön edelle. Päinvastoin hänelle"yleinen on yksityistä tärkeämpi: kansa ja valtio ovat enemmän kuin yksilö" (Arwidsson 1821/1909, 171). Tässä hän lyö kättä Saiman Snellmanin kanssa, joka myös oli liberaali yksissä jos toisissakin suhteissa, mutta joka "vastusti jyrkästi liberaalien liiallista yksilökeskeisyyttä" (Kinnunen 1981, 13). Vaikka Arwidsson ei ollut perehtynyt Hegelin ajatteluun kuten Snellman, molemmat ajattelivat hegeliläisittäin, että" yksilön käsitettä edeltää yhteisön käsite" ja että yksilöllä on velvoite toimia "yhteisen hyvän vuoksi" oman tai edustamansa ryhmän edun sijasta (Pulkkinen 1996, 199). Klassisessa liberalismissa taas yksilön tai hänen ryhmänsä etu on ensisijainen ja yhteinen hyvä toteutuu, jos on toteutuakseen, oman tai ryhmäedun ajamisen tietä.

Yhteisöpainotteinen ajattelu voi helposti johtaa katsomukseen, että valtaapitävät tietävät "yhteisen hyvän" parhaiten ja ettei kriittinen julkinen keskustelu ole näin ollen lainkaan tarpeen. Arwidsson ja Snellman menivät kuitenkin päinvastaiseen suuntaan. Arwidsson (1821/1909, 174) motivoi kansalaislähtöistä julkisuutta nimenomaan korostamalla sen merkitystä valtion kehityksen ja siten yhteisen hyvän etsimisen kannalta:

Olemme nähneet, että valtio ja sen hallitus kaikkine muotoineen on luonteeltaan julkinen. Kaikki, mikä vaikuttaa sen hengen kehittämiseen, on siis mitä tärkein sille. Julkisella äänellä, joka peittelemättä esittää kaikkia yhteiskunnallisia oloja, joka vapaasti lausuu mielipiteensä olevista muodoista, niiden hyödyllisyydestä, eduista ja hoitamisesta, tulee välttämättä olla siinä mitä suurin vaikutus. ${ }^{15}$

Vuonna 1846 Snellman $(1846 / 2005,97)$ tarkasteli Saima-lehdessään vastaavaan sävyyn mutta jäsentyneemmin kuin Arwidsson mahdollisuutta päätyä julkisessa keskustelussa yksimielisyyteen eri asioissa. Tämä edellyttää, että lehdistö 
välittää nuo asiat maan ajattelevien ihmisten osallistumisen kohteiksi. Moni tällainen mies osoittaa tämän osallistumalla itse lehtien palstoilla käytävään keskusteluun; toiset toimivat mielipiteensä puolesta pienemmissä piireissä ja järkevin käsitys puheena olevasta asiasta voittaa vähitellen kannatusta kunnes lähes kaikki sitä vastustavat äänet vaimenevat. Kun sitten [...] hallintoelimet asettavat tuon kysymyksen eri yhteiskuntaluokkia ja maan eri osia edustaville miehille, he saavat kaikkialla saman vastauksen eikä tällä tavoin meneteltäessä voida erehtyä siitä, mitä yleinen etu tässä tapauksessa vaatii.

Näin sanoessaan Snellman selvästikin artikuloi näkemystä, jonka mukaan keskustelijat eivät aja "omia etujaan, vaan he esiintyvät henkilöinä, jotka ovat asettuneet hakemaan yleistahdon ilmausta ja väittävät olevansa paremmin yleistahdon palveluksessa kuin toiset" (Pulkkinen 1996, 199). Julkisessa keskustelussa punnitaan se,"mikä mielipide on järkevin ja siksi yleisin" (Snellman 1844/2005, 306). Kuten havaittiin, Arwidssonkin ajatteli tähän suuntaan, vaikka hänellä julkisen keskustelun asema ja rooli jäivätkin epämääräisemmiksi kuin Snellmanilla.

\section{GRANDE FINALE}

Onko näillä arkkivaarien aatoksilla jotain annettavaa julkisuusteorialle vai onko niillä enää vain antikvaarista mielenkiintoa? Tähän voi vastata, että annettavaa ei ole niinkään heidän aatoksillaan sinänsä kuin sillä visiolla julkisuudesta, jota ne ilmentävät. Olen tuonut edellä jo pariin otteeseen esiin sen, että tämä Forsskålin ja Chydeniuksen alustavista hahmotelmista Arwidssonin kautta Snellmanin kiteyttämään muotoon etenevä visio vastaa Habermasin hahmotelmaa porvarillisesta julkisuudesta siltä osin kuin julkisuuden katsotaan rakentuvan valtaapitävien toimia arvioivassa julkisessa keskustelussa. Toisaalta arkkivaarien julkisuusvisio eroaa eräässä hyvin tärkeässä kohdassa porvarillisen julkisuuden hahmotelmasta. Tämän kohdan osoittamiseksi on syytä palata vielä lyhyesti Snellmaniin.

Kirjoittaessaan sananvapaudesta Litteraturbladissa vuonna 1862 Snellman $(1862 / 2005,402)$ teki eron kansalaisyhteiskunnan ja valtion välillä todeten, että kun edellisessä"yksilö toimii omien etujensa hyväksi, valtiossa hänen on toimittava yleisten etujen, kansakunnan edun hyväksi." ${ }^{16}$ Hän katsoi, että sananvapaus ei ole kansalaisyhteiskunnan piiriin kuuluva"kansalaisvapaus" vaan valtion piiriin kuuluva "poliittinen oikeus" (emt., 403), joten sitä ei tule käyttää yksityisetujen edistämiseen vaan juuri yleisten etujen, kansakunnan edun hyväksi. Siten hän sijoitti julkisuuden selvästi valtion piiriin ja löi lukkoon sen aiemman kolmikon aloittaman linjan, jonka mukaan julkisuus on toimintaa, jossa valtio kehittää itseään valtiokansalaistensa julkisen keskustelun voimin.

Habermasilla (2004, 57-61) porvarillinen julkisuus taas sijoittuu selvästi kansalaisyhteiskunnan piiriin. Se on (tai oli) toimintaa, jossa "julkisoksi kokoontuneet yksityishenkilöt" välittivät keskustelunsa kautta kansalaisyhteiskunnan etuja" valtioon päin" (emt., 257). Arkkivaarien anti julkisuusteorialle on siten siinä, että he artikuloivat klassisen porvarillisen julkisuuden rinnalle aina-

Tiedotustutkimus 2008:3 
kin retorisesti toisen historiallisen mallin, joka porvarillisen julkisuuden mallin tavoin on vastakkainen autoritaariselle, ylhäältä alas suuntautuvalle julkisuudelle. ${ }^{17}$ Jos porvarillinen julkisuus edustaa liberalismia (vrt. emt., 120-126), arkkivaarien mallia voitaneen kutsua kommunitaariseksi. ${ }^{18}$ Se ei jäänyt vain teorian tasolle vaan suomalainen julkisuus oli ainakin jossain määrin sen mukainen 1800-luvun loppupuoliskolla. Entäpä nyt? Väittäisin, että yhteisessä veneessä olemisen retoriikka jäsentää osaltaan edelleenkin julkisuutta, vaikka sananvapaus on jo aikapäivät sitten kiepahtanut palvelemaan etupäässä niitä etuja, joita sen Snellmanin mukaan ei pitänyt palvella.

\section{Viitteet}

1 Tämä kuvaus muistuttaa Habermasin (2004, 62-79) esitystä julkisuuden varhaisten laitostumien kehkeytymisestä Englannissa, Ranskassa ja Saksassa.

2 Habermasin (2004, 91-93) mukaan vallankäytön salailukäytännön vastustus on yleensäkin ollut yksi keskeisistä etapeista matkalla kohti porvarillista julkisuutta.

3 Kuvatessaan poliittisen julkisuuden muotoutumista Englannissa Habermas $(2004,99)$ toteaa, että sielläkin tuo julkisuus alkoi rakentua, kun poliittisesti toimivat tahot kääntyivät kansalaisten puoleen "saadakseen vaatimuksilleen pontta".

4 Suomeksi kirjoituksen on julkaissut mm. J.D. Danielson-Kalmari (1932, 355-362). Tähän artikkeliin otetut suorat lainaukset olen silti kääntänyt itse.

5 Jo vuonna 1756 Forsskål oli saavuttanut filosofian maisterin ja tohtorin arvon Göttingenissä hyväksytyllä väitöskirjallaan Dubia de principiis pbilosophiae recentionis (Uudemman filosofian periaatteita koskevia epäilyksiä). Sen yhtenä teemana oli moraali, jonka Forsskål ajatteli Matinollin $(1960,52)$ tulkinnan mukaan - edellyttävän "ehdottomasti tahdon vapautta". Tämä ennakoi kansalaisvapauskirjoituksen vapausteemaa eli tältä osin tuo kirjoitus on tavallaan jatkoa Göttingenin väitöskirjalle (vrt. Patoluoto 1989, 34). - Huomattakoon, että tuonaikaiset väitöskirja- ja oppiarvokäytännöt eroavat melkoisesti nykyisistä.

6 Forsskål puolustautui laajassa kirjelmässä kansliakollegion arviota vastaan pitäen tiukasti kiinni sananvapausperiaatteistaan. Danielson-Kalmari $(1932,374-378)$ on julkaissut kirjelmästä osan suomeksi.

7 Lopullisen version on julkaissut ruotsiksi mm. Kastari (1981,72-77). Sikäli kuin seuraavassa esiin tulevien suorien lainausten kohdat ovat samat näissä versioissa, olen suomentanut ne lopullisen version pohjalta itse, koska luonnoksen suomennos on kehnonpuoleinen (vrt. emt., 2-3; Virrankoski 1986, 20; 26). Yhden lopullisesta versiosta poistetun kohdan suomennoksena olen hyödyntänyt Virrankosken käännöstä.

8 Manninen (1996, 95-101) on tarkastellut tätä kysymystä laajemmin ja huomauttanut, että valtiosääntöasiakirjoissa jäi epäselväksi, viitattiinko valtakunnan säädyillä valtiopäivillä istuviin edustajiin vai heidän valitsijoihinsa. Käytännössä asia tulkittiin edellisen vaihtoehdon mukaan, mikä juuri merkitsi edustajien vapaata valtuutusta. Mutta vaikka se olisi tulkittu toisinkin päin, tämä ei suinkaan olisi merkinnyt vielä kansanvaltaa.

9 Chydenius osallistui asetuksen kehittelyyn valtiopäivillä aina siihen asti, kunnes hänet erotettiin pappissäädystä hänen jouduttuaan pahaan ristiriitaan myssypuolueen johdon kanssa.

10 Asetuksen 4 §:n toinen kappale. Asetuksen on julkaissut ruotsiksi mm. Kastari (1981, 79-86). 
11 Esimerkiksi lehden perustamiseen oli haettava viranomaisilta lupa, jossa määriteltiin muun muassa lehdelle luvalliset aihepiirit. Epäselvyyttä näyttää vallinneen siitä, kenen tuli valvoa lupaehtojen täyttämistä ja puuttua niitä rikottaessa asiaan (ks. Castrén 1951, 206-220).

12 Esimerkiksi hänen ajattelussaan oli Forsskålin ja Chydeniuksen tavoin "tärkeällä sijalla elinkeinoelämän vapautus merkantilistisista kahleista ja vapaakaupan käytäntöön otto" (Castrén 1951, 192).

13 Samantapaista ajatuskuviota edustaa historiallisen materialismin näkemys tuotantovoimista, jotka alati kasvavina ajautuvat lopulta ristiriitaan kulloistenkin tuotantosuhteiden kanssa. Ristiriidat ratkaistaan uudet tuotantosuhteet pysyttävissä vallankumouksissa.

14 Tässä suomennoksen termi yleisö on muutettu termiksi julkiso.

15 Huomattakoon, että Arwidsson tarkoittaa julkisella äänellä nimenomaan sanomalehtiä.

16 Tähän kohtaan Snellmanin kirjoituksissa huomioni kiinnitti se, mitä Kauko Pietilä on tuonut hänestä esiin "Tiedotusopillinen ajattelu ja tutkimus" -luennossaan syyslukukaudella 2007.

17 Tosin kaikki arkkivaarit puhuivat vapaan elinkeinoelämän puolesta ja artikuloivat näin kansalaisyhteiskunnan tiettyjen piirien etuja. He eivät silti kytkeneet ajattelunsa tätä puolta niin tiiviisti julkisuusproblematiikkaan, että olisivat perustelleet sananvapautta nimenomaan kansalaisyhteiskunnan etujen julkilausumista painottavin perusteluin.

18 Nancy Fraser $(1992,129-131)$ on puhunut samantapaisesta julkisuusmallista termillä civic republican. Hän ei kytke sitä kuitenkaan valtiolliselle tai kansalliselle tasolle vaan hänelle se edustaa yhtä hänen porvarillisessa julkisuudessa näkemäänsä puolta (kommunitarismista tai republikanismista ks. myös Habermas 1996 ja 1998, 324-348).

\section{Kirjallisuus}

Ammondt, Jukka (1992) Adwidsson romantikkona ja runoilijana. Teoksessa Jokipii, Mauno (toim.) Adolf Ivar Arwidsson: näkijä ja tekijä. Jyväskylä: Atena.

Arwidsson, A.I. ([1821] 1909) Painovapaus ja julkisuus. Teoksessa Adolf Ivar Arwidssonin tutkimuksia ja kirjoitelmia (suom. Severi Nuormaa ja Edv. Rein). Helsinki: Suomalaisen kirjallisuuden seura. (Ensijulkaisu 1821.)

Arwidsson, A.I. ([1823] 1909) Elämänvaiheeni [1791-1823]. Teoksessa Adolf Ivar Arwidssonin tutkimuksia ja kirjoitelmia (suom. Severi Nuormaa ja Edv. Rein). Helsinki: Suomalaisen kirjallisuuden seura. (Ensijulkaisu 1823.)

Castrén, Liisa (1951) Adolf Ivar Arwidsson isänmaallisena herättäjänä. Historiallisia tutkimuksia $x_{x x v}$. Helsinki: Suomen historiallinen seura.

Chydenius, Antti ([1765] 1929) Nöyrä mietintö. Teoksessa Antti Chydeniuksen valitut teokset (toim. ja suom. V. Malinen). Porvoo: WSOY. (Ensijulkaisu 1765.)

Danielson-Kalmari, J.D. (1932) Suomen valtio- ja yhteiskuntaelämää 18:nnella ja 19:nnellä vuosisadalla. Piirteitä vapaudenajalta. Toinen osa: Yhteiskunnallisia virtauksia. Porvoo: WSOY.

Fraser, Nancy (1992) Rethinking the Public Sphere. Teoksessa Calhoun, Craig (toim.) Habermas and the Public Sphere. Cambridge, MA: The MIT Press.

Forsskål, Pehr ([1759] 1989) Tankar om borgerliga friheten. Tiede \& edistys, 14:1, 27-31. (Ensijulkaisu 1759.)

Habermas, Jürgen (1996) Three Normative Models of Democracy. Teoksessa Benhabib, Seyla (toim.) Democracy and Difference. Princeton, NJ: Princeton University Press.

Habermas, Jürgen (1998) Faktizität und Geltung. Suhrkamp Taschenbuch Wissenschaft 1361. Frankfurt am Main: Suhrkamp.

Habermas, Jürgen (2004) Julkisuuden rakennemuutos (suom. Veikko Pietilä). Tampere: Vastapaino. (Ensijulkaisu 1962.)

Holmberg, Claes-Göran; Ingemar Oscarsson \& Per Rydén (1983) En svensk presshistoria. Esselte Studium. Stockholm: Norsteds tryckeri. 
Holmberg, Claes-Göran, Ingemar Oscarsson \& Jarl Torbacke (2000) Den svenska pressens historia, 1, I begynnelsen (tiden fore 1830). Västervik: Ekelids förlag.

Junnila, Olavi (1979) Adolf Iwar Arwidsson. Helsinki: Kirjayhtymä.

Kastari, Pirkko-Liisa (1981) Antti Chydenius ja painovapauden aate. Tampereen yliopisto. Tiedotusopin laitoksen julkaisuja B:5.

Kinnunen, Matti (1981) J.V. Snellmanin sanomalehtiuran alku ja Saima. Julkaisussa J.V. Snellman ja sanomalehdistö, 10-25. Suomen sanomalehdistön historiaprojektin julkaisuja n:o 19.

Klinge, Matti (2004) Poliittinen Runeberg. Helsinki: WSOY.

Leino-Kaukiainen, Pirkko (1996) Sananvapaus sääty-yhteiskunnassa. Kamppailu sensuuria vastaan autonomian aikana. Teoksessa Nordenstreng, Kaarle (toim.) Sananvapaus. Helsinki: WSOY.

Manninen, Sami (1996) Kirjoitusvapaus ja valtiopäiväjulkisuus. Vuoden 1766 painovapausasetuksen tarkastelua. Teoksessa Nordenstreng, Kaarle (toim.) Sananvapaus. Helsinki: WSOY.

Matinolli, Eero (1960) Petter Forsskål: luova ihminen 1700-luvun Pohjolasta. Turun yliopiston julkaisuja, sarja B, osa 79.

Patoluoto, Ilkka (1989) Forsskålin ajattelun tausta ja luonne. Tiede \& edistys 14:1, 32-36.

Pietilä, Veikko (1997) Joukkotiedotustutkimuksen valtateillä. Tampere: Vastapaino.

Pulkkinen, Tuija (1996) Snellmanin perintö suomalaisessa sananvapaudessa. Teoksessa Nordenstreng, Kaarle (toim.) Sananvapaus. Helsinki: WSOY.

Rommi, Pirkko (1992) Tienhaarassa - nuoren Arwidssonin poliittinen toiminta. Teoksessa Jokipii, Mauno (toim.) Adolf Ivar Arwidsson: näkijä ja tekijä. Jyväskylä: Atena.

Snellman, J.V* ((1844] 2005) Julkinen sana. Teoksessa J.V. Snellman, Kootut teokset, osa 6. Helsinki: Opetusministeriö. (http://www.vnk.fi/tiedostot/pdf/fi/81395.pdf [26.8.2005])

Snellman, J.V* ([1846] 2005) Yleinen mielipide. Teoksessa J.V. Snellman, Kootut teokset, osa 9. Helsinki: Opetusministeriö. (http://www.vnk.fi/tiedostot/pdf/fi/82959.pdf [26.8.2005])

Snellman, J.V. ([1862] 2005) Sananvapaudesta. Teoksessa J.V. Snellman, Kootut teokset, osa 18. Helsinki: Opetusministeriö. (http://www.vnk.fi/tiedostot/pdf/fi/82959.pdf [13.9.2007])

Tommila, Päiviö (1980) Sensuuriolot ennen vuotta 1865. Teoksessa Leino-Kaukiainen, Pirkko (toim.) Sensuuri ja sananvapaus Suomessa. Suomen sanomalehdistön historiaprojektin julkaisuja n:o 17 .

Tommila, Päiviö (1988) Yhdestä lehdestä sanomalehdistöksi 1809-1859. Teoksessa Tommila, Päiviö (toim.) Suomen lehdistön historia 1: Sanomalehdistön vaiheet vuoteen 1905. Kuopio: Kustannuskiila.

Virrankoski, Pentti (1986) Anders Chydenius: demokraattinen poliitikko valistuksen vuosisadalta. Porvoo: WSOY.

Zilliacus, Clas \& Henrik Knif (1985) Opinionens tryck: en studie över pressens bildningsskede i Finland. Helsingfors: Svenska Litteratursällskapet i Finland. 